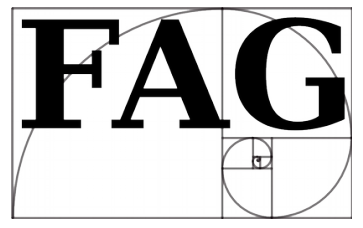

Filozoficzne Aspekty Genezy — 2017, t. 14

Philosophical Aspects of Origin

s. $53-87$

ISSN 2299-0356

http://www.nauka-a-religia.uz.zgora.pl/images/FAG/2017.t.14/art.02.pdf

Jonathan Bartlett

\title{
Filozoficzne wady naturalizmu metodologicznego i perspektywy na przyszłość *
}

Podstawą naturalizmu metodologicznego, służącego wzmocnieniu ekskluzjonistycznego poglądu na badania naukowe, są trzy problematyczne nurty filozofii: filozofia mechanistyczna, pozytywistyczna epistemologia i doktryna niepojmowalności Boga. Każda z tych filozofii posiada wewnętrzne wady, przez które stanowiska te nie są w stanie objać pełnego zakresu związków przyczynowych, jakie usiłuje badać nauka. Jednak pomimo tych problemów, omawiany tu rodzaj naturalizmu wykazuje, jako metodologia, pewne pozytywne cechy, które należałoby zachować, nawet jeżeli sam naturalizm metodologiczny jest nie do utrzymania.

\section{Definicja naturalizmu metodologicznego}

Naturalizm metodologiczny miał wielu zwolenników i w różny sposób był definiowany. Próba uporządkowania tych definicji może okazać się trudna. Każdy zwolennik ma swój własny pogląd na to, czym naturalizm metodologiczny \footnotetext{
org.

Jonathan Bartlett, M.T.S. — The Blyth Institute, e-mail: jonathan.bartlett@blythinstitute.

(C) Copyright by Jonathan Bartlett, Blyth Institute Press, Dariusz Sagan \& Filozoficzne Aspekty Genezy.

* Jonathan Bartlett, „Philosophical Shortcomings of Methodological Naturalism and the Path Forward", w: Jonathan Bartlett and Eric Holloway (eds.), Naturalism and Its Alternatives in Scientific Methodologies: Proceedings of the 2016 Conference on Alternatives to Methodological Naturalism, Blyth Institute Press, Broken Arrow, Oklahoma 2017, s. 13-37. Za zgodą Autora i Wydawnictwa z języka angielskiego przełożył: Dariusz SAgAN.
} 
jest, dlaczego jest ważny i jakie ma znaczenie dla nauki. Do obozu zwolenników naturalizmu metodologicznego zaliczają się zarówno ci, którzy uważają, że wyjaśnienia nienaturalistyczne mieszczą się $\mathrm{w}$ granicach nauki, ale nie są zbyt płodne, jak i ci, według których takie wyjaśnienia należy wykluczyć z nauki a priori.

Większość twierdzeń na temat naturalizmu metodologicznego zaliczyć można do obozu apriorycznego ekskluzjonizmu. Pogląd apriorycznego ekskluzjonizmu jest najważniejszy, ponieważ można go użyć, i używano go, jako regułę trzymaną w rękach jednego obozu, dzięki której z dziedziny nauki wyklucza się badania innego obozu.

W artykule skupię się na poglądzie ekskluzjonistycznym z dwóch powodów. Przede wszystkim, skoro rozpatrujemy problem z perspektywy filozoficznej, to nie interesuje nas kwestia, czy ktoś uznaje prywatnie, że naturalizm jest pomocny lub nie. To, co obecnie ludzie uważają za pomocne, niewiele mówi o ontologii lub epistemologii w ogólniejszym sensie. Po drugie, ścisły ekskluzjonizm stosowany jest jako reguła umożliwiająca wykluczanie odkryć innych badaczy. Innymi słowy, wyłącznym celem ścisłego ekskluzjonizmu nie jest oznajmienie przez kogoś, co on sam robi lub dlaczego wybrał daną metodologię, lecz wykluczenie z dyskusji tych, którzy dokonali innego wyboru. Racjonalne uzasadnienie takiego aktu wykluczenia wymaga znalezienia mocnej po temu podstawy. Jeśli wolę badać rzekotki drzewne, a nie welociraptory, to może być to wybór podyktowany jakimiś racjami, ale nie muszę go uzasadniać nikomu innemu oprócz siebie. Jeżeli jednak chcę zabronić innym prowadzenia badań i publikowania na temat welociraptorów, to muszę mieć do tego mocne filozoficzne podstawy, które z kolei muszą podlegać intersubiektywnej analizie. Podobnie, jeśli ktoś chce ograniczyć się we własnych badaniach do naturalistycznych przyczyn i metod, to inni nie powinni się tym przejmować. Jeżeli jednak ktoś chce zabronić innym rozpatrywania nienaturalistycznych przyczyn i metod, to muszą przemawiać za tym silne racje.

Najbardziej autorytatywne oświadczenie na temat naturalizmu metodologicznego wydało National Science Teachers Association (NSTA). Później zostało ono powielone przez inne autorytatywne grupy, takie jak National Academy of Sciences (NAS). Najczęściej przytaczana wersja tego oświadczenia pojawiła się w wydanej w 1998 roku przez NAS książce Teaching About Evolution 
and the Nature of Science [Nauczanie o ewolucji i naturze nauki]. Oto wersja oświadczenia z tej książki:

Nauka to metoda wyjaśniania świata przyrody. Zakłada ona, że Wszechświat funkcjonuje na podstawie prawidłowości, które możemy zrozumieć dzięki systematycznym badaniom. Metodologia nauki kładzie nacisk na logiczne testowanie alternatywnych wyjaśnień dla zjawisk przyrodniczych w odniesieniu do danych empirycznych. Ponieważ nauka zajmuje się wyjaśnianiem świata przyrody wyłącznie za pomocą procesów naturalnych, więc nie może odwoływać się do przyczynowości nadnaturalnej w swoich wyjaśnieniach. Podobnie nauka nie może formułować twierdzeń o siłach nadnaturalnych, ponieważ wykraczają one poza zakres jej kompetencji. Nauka doprowadziła do wzrostu naszej wiedzy właśnie dlatego, że kładzie nacisk na poszukiwanie przyczyn naturalnych. ${ }^{1}$

Z biegiem lat NSTA aktualizowało swoje oświadczenie, ale $\mathrm{w}$ duchu pozostało ono zasadniczo takie samo. Oto nowa jego wersja:

Nauka to metoda testowania naturalistycznych wyjaśnień dla przyrodniczych obiektów lub zdarzeń. Przedmiotem badań naukowych są zjawiska, które można obserwować lub mierzyć. Nauka opiera się także na obserwacji, że Wszechświat funkcjonuje na podstawie prawidłowości, które można odkryć i zrozumieć dzięki badaniom naukowym. Wyjaśnienia niespójne z danymi empirycznymi lub niemożliwe do empirycznego przetestowania nie należą do dziedziny nauki. W rezultacie wyjaśnienia zjawisk przyrodniczych nieoparte na danych empirycznych, lecz wywodzące się z mitów, prywatnych przekonań, wartości religijnych, aksjomatów filozoficznych i przesądów nie są naukowe. Ponadto, ponieważ nauka zajmuje się wyłącznie wyjaśnianiem zjawisk przyrodniczych poprzez testowanie ich $w$ odniesieniu do danych empirycznych, więc nie może dostarczać wyjaśnień religijnych lub ostatecznych. ${ }^{2}$

W zamyśle oba oświadczenia zawierają tezy normatywne dla praktyki naukowej. Używano ich też jako podstawy do rozwijania standardów naukowych $\mathrm{i}$ uzasadniano za ich pomocą wykluczenie z nauki innych form dociekań. ${ }^{3} \mathrm{Z}$ ra-

\footnotetext{
${ }^{1}$ Working Group on Teaching Evolution, National Academy of Sciences, Teaching About Evolution and the Nature of Science, National Academy Press, Washington, DC. 1998, s. 124, http://www.nap.edu/read/5787/chapter/1 (11.07.2017).

${ }^{2}$ National Science Teachers Association, „NSTA Position Statement on the Teaching of Evolution", 2013, http://www.nsta.org/about/positions/evolution.aspx (11.07.2017).

${ }^{3}$ Por. NGSS Lead States, „Appendix h: Understanding the Scientific Enterprise: The Nature of Science in the Next Generation Science Standards", w: Next Generation Science Standards: For States, By States, National Academies Press, Washington, DC. 2013, s. 430-436; SC Educa-
} 
cji tego, że oświadczenia te zostały wydane przez normatywne instytucje (NAS i NSTA), jak i przez wzgląd na historię posługiwania się nimi w celu wykluczania pewnych badań, to właśnie na nie położony zostanie nacisk w niniejszym artykule.

\section{Identyfikacja intelektualnych źródel oświadczenia NSTA}

W ostatnich latach wielu naukowców lekceważyło filozofię jako wartościowe źródło wiedzy. Jak widać na przykładzie wyżej przytoczonej nowej, zaktualizowanej wersji oświadczenia NSTA, stowarzyszenie to jawnie odrzuca aksjomaty filozoficzne jako źródło wiedzy naukowej. Problem z odrzucaniem filozofii jako źródła wiedzy polega na tym, że podkopuje to fundamenty samej nauki. Podstawą większości dociekań naukowych jest zasada racji dostatecznej oraz zasada identyczności przedmiotów nieodróżnialnych. ${ }^{4}$ Zasady te weszły do nauki z filozofii, co wskazuje, że niemal cała wiedza naukowa w rzeczywistości wywodzi się z filozoficznych aksjomatów. Jeżeli ktoś bada jakąś substancję, stwierdza, że jej właściwości są takie jak wodoru, i dochodzi do wniosku, że to jest wodór, to ten ktoś, przeprowadzając rozumowanie od danych empirycznych do wniosku stwierdzającego, że badana substancja jest wodorem, wykracza poza dane empiryczne i stosuje zasadę identyczności przedmiotów nieodróżnialnych jako aksjomat filozoficzny.

W rzeczy samej, jak wykazało to wielu filozofów nauki, nawet tak zwane fakty empiryczne opierają się na modelach, a więc ich podstawą są aksjomaty filozoficzne. ${ }^{5}$ Jak wykażę $\mathrm{w}$ tym artykule, u podstaw wielu takich modeli leżą

tion Oversight Committee, „Special Panel of the State Board of Education and EOC Regarding High School Biology Standard H.B.5. (July 29, 2014)", http://tiny.pl/g18nw; Lawrence C. Scharmann, „A Proactive Strategy for Teaching Evolution”, The American Biology Teacher 2015, vol. 67, no. 1, s. 12-16; Lawrence S. Lerner, Good Science, Bad Science: Teaching Evolution in the States, Thomas B. Fordham Foundation 2000, https://edex.s3-us-west-2.amazonaws. com/publication/pdfs/lerner_7.pdf (12.07.2017); Richard B. KATsKEE, „Why It Mattered to Dover That Intelligent Design Isn't Science", First Amendment Law Review 2006, vol. 5, s. 112-146, $\mathrm{http}: / /$ tiny.pl/g18np (12.07.2017).

${ }^{4}$ Por. Jonathan BARTLETT, „Introduction”, w: Jonathan BARTLETT, Dominic HalsMER, and Mark Hall (eds.), Engineering and the Ultimate: An Interdisciplinary Investigation of Order and Design in Nature and Craft, Blyth Institute Press, Broken Arrow, Oklahoma 2014, s. 1-8.

${ }^{5}$ Por. Michael Polanyi, Science, Faith, and Society, Oxford University Press, Oxford 1946; Norwood Russell Hanson, Patterns of Discovery, Cambridge University Press, Cambridge 1958; 
prywatne przekonania, a także to, co NSTA z pewnością zaliczyłoby do kategorii „mitów”.

Jednakże w tej chwili chodzi o to, że naukowcy jako grupa, a zwłaszcza reprezentujące ich organizacje naukowe, najwyraźniej zupełnie nie zdają sobie sprawy z roli, jaką w ich rozumowaniu odgrywa filozofia. W takim układzie bardzo trudno uzyskać od naukowców jawne wyjaśnienie, jaka filozofia leży u podstaw tego, co robią i jak opisują to, co robią. Nie znaczy to, że nie posiłkują się oni żadną filozofią, a jedynie, że są nieświadomi, jaka jest to filozofia, skąd się ona wywodzi i jakie ma ograniczenia.

Każdej filozofii nieodłącznie towarzyszą pewne uprzedzenia. Celem filozofii nie jest ich eliminowanie, lecz zbadanie. Gdy ktoś sądzi, że nie posługuje się filozofią, zwykle znaczy to, że żywi on uprzedzenia płynące z filozofii, ale nie jest tego świadomy i nie jest w stanie krytycznie ich zbadać. Toteż celem ustalenia filozoficznych podstaw wyżej wskazanych sformułowań naturalizmu metodologicznego jest wydobycie ich na powierzchnię, aby można je było zbadać w świetle dnia i aby nie utrzymywano ich już wyłącznie jako uprzedzeń.

Celem tego artykułu jest ukazanie nurtów filozofii, które leżą u podstaw naturalizmu metodologicznego ( $\mathrm{w}$ rozumieniu wyrażonym $\mathrm{w}$ oświadczeniach NSTA), a następnie krytyczna analiza, która pokaże, że nie mogą one stanowić filozoficznego fundamentu nauki.

Filozofia stojąca za jakąś poszczególną metodologią naukową nie miałaby tak dużego znaczenia, gdyby ta metodologia obowiązywała w ramach jakiegoś izolowanego przedsięwzięcia naukowego. Można by wówczas całkiem rozsądnie twierdzić, że ograniczenia metodologiczne nie wywodzą się z jakiejś konkretnej, uniwersalnej filozofii, lecz z natury przedmiotu badań. Naturalizm metodologiczny to jednak teza nie tylko o jakiejś szczególnej dziedzinie nauki, lecz o wszystkich naukach przyrodniczych. Choć nauka ma swój początek w fizyce, obecnie obejmuje ona różne dziedziny, wliczając w to biologię, antropologię, psychologię, kosmologię i teorię ewolucji, a każda z nich ma swoje własne przedmioty badań. Zgodnie $\mathrm{z}$ naturalizmem metodologicznym każda $\mathrm{z}$ nich,

Willard Van Orman Quine, „Ontological Relativity”, The Journal of Philosophy 1968, vol. 65, no. 7, s. 185-212; Paul K. Feyerabend, Przeciw metodzie, przeł. Stefan Wiertlewski, Siedmioróg, Wrocław 2001; John Polkinghorne, Belief in God in an Age of Science, Yale University Press, New Haven and London 1998, s. 101-124. 
jako dziedzina naukowa, musi podlegać tym samym ograniczeniom metodologicznym, co fizyka. Na dodatek dwie ze wspomnianych dziedzin - kosmologia i teoria ewolucji - to dziedziny totalizujace. Znaczy to, że prawdziwość ich ustaleń jest zależna od wzięcia pod uwagę wszystkich dostępnych przyczyn. Nie można po prostu wybrać jednego, zawężonego przedmiotu badań, ograniczyć się do jakiegoś podzbioru przyczyn i uzyskać wiążące wyniki. Kosmologia, na przykład, zajmuje się całymi dziejami Wszechświata. Jeżeli gdziekolwiek we Wszechświecie działają przyczyny niewchodzące w zakres naturalizmu metodologicznego, to kosmologowie mogą pomijać ważne przyczyny tylko ze względu na ograniczenia metodologiczne narzucone $\mathrm{z}$ zewnątrz. Podobnie jest $\mathrm{w}$ przypadku teorii ewolucji. Jeśli w dziejach życia działają przyczyny wykluczane przez naturalizm metodologiczny, to ewolucjoniści mogą pomijać ważne przyczyny konieczne do odkrycia prawdy o ewolucji ziemskiego życia. Podkreślmy raz jeszcze, że skoro są to dziedziny totalizujące, to takich ograniczeń nie można postrzegać jako związanych $\mathrm{z}$ samymi przedmiotami badań, ponieważ w tym wypadku należy rozważyć każdą dostepna przyczynę w dziejach przedmiotu badań, nie zaś tylko te rozważane w jakimś szczególnym kontekście (to jest w kontekście badań laboratoryjnych czy eksperymentów).

Możemy więc również powiedzieć, że ponieważ naturalizm metodologiczny stosowany jest w nauce bez względu na przedmiot badań, a także w naukach totalizujących, więc jego podstawą musi być nie przedmiot badań, lecz dominująca filozofia przyrody i epistemologia. W takim wypadku koniecznością jest obnażenie i przeanalizowanie filozofii stojących za naturalizmem metodologicznym.

\section{Trzy nurty filozofii}

W artykule tym argumentuję, że naturalizm metodologiczny ma źródło w trzech nurtach myśli: filozofii mechanistycznej, pozytywistycznej epistemologii i teologicznej doktrynie niepojmowalności Boga. Nurty te są tworzą synergię, gdyż zapewniają sobie nawzajem uzasadnienie przyjmowanych w nich założeń. Produktem współdziałania tych nurtów jest naturalizm metodologiczny w rozumieniu wyrażonym w oświadczeniu NSTA.

Pierwszym nurtem jest filozofia mechanistyczna, czyli filozofia przyrody powstała w siedemnastym wieku. Przyjęła ona różne formy (które tu zbadamy), 
ale zasadniczo chodzi w niej o to, by przyrodę postrzegać jako swego rodzaju maszynę. Filozofię tę można uznać za reakcję na scholastyczną filozofię przyrody, która cieszyła się popularnością w średniowieczu. Siedemnastowieczni filozofowie uważali, że wyjaśnienia filozofów scholastycznych tak naprawdę żadnymi wyjaśnieniami nie są. ${ }^{6}$ Scholastycy postrzegali świat jako składający się $\mathrm{z}$ form substancjalnych i jakości. W oczach filozofów mechanistów te formy i jakości same wymagały wyjaśnienia. Stwierdzenie, że coś jest „suche”, ponieważ w większym stopniu posiada jakość ,suchości”, nie wydaje się rzeczywiście wyjaśniać suchość. Podobnie stwierdzenie, że coś jest okragłe, ponieważ jego forma ma kolisty charakter, w istocie nie mówi nic o tym, dlaczego to coś ma taki kształt.

Zgodnie więc $\mathrm{z}$ filozofią mechanistyczną pełniejsze wyjaśnienia świata można zapewnić wówczas, gdy świat potraktuje się jako maszynę i zada się pytanie, jakie rodzaje mechanizmów tworzą formy i jakości obserwowane w przyrodzie.

W wieku dziewiętnastym filozofia mechanistyczna zrodziła epistemologiczne stanowiska pozytywizmu i jego kuzyna - pragmatyzmu. Pozytywizm to idea, że każde twierdzenie, którego nie można ująć w kategoriach materii i ruchu (czyli w fundamentalnych kategoriach filozofii mechanistycznej), jest nie tylko błędne, ale wręcz bezsensowne. Na przykład słowo „miłość” ma znaczenie jedynie wówczas, gdy można podać operacyjną definicję miłości, jak choćby taką: „Miłość znaczy, że ktoś będzie mnie często przytulać”. W myśl pozytywizmu wszystkie terminy, aby mieć ważne znaczenie, muszą być ostatecznie definiowalne w kategoriach operacyjnych (to jest mechanistycznych). Pozytywizm zaprzeczył realności większości duchowych istot, sił i idei, stwierdzając, że skoro ich podstawowego znaczenia nie da się zdefiniować w kategoriach operacyjnych, to nie mogą być bytami poznawalnymi.

Pragmatyzm jest podobny do pozytywizmu, ale przyjmuje nieco inną strategię. Celem pozytywizmu jest zdobycie wiedzy prawdziwej, którą sprowadza się do rzeczy poznawalnych w kategoriach operacyjnych. Pragmatyzm, z drugiej strony, nie poszukuje prawdziwej wiedzy, lecz idei posiadających „wartość pie-

\footnotetext{
${ }^{6}$ Por. Edward SLowiK, „Descartes' Physics”, w: Edward N. ZALTA (ed.), The Stanford Encyclopedia of Philosophy, Summer 2014 Edition, https://plato.stanford.edu/archives/sum2014/ent ries/descartes-physics/ (02.08.2017).
} 
niężną". Dla pragmatyzmu w ogóle nie jest ważne, czy jakiekolwiek terminy lub związki, jakimi się posługuje, mają ugruntowanie w rzeczywistości. Interesuje go jedynie, czy pewne rozważania nad rzeczywistością okazują się skuteczne, czy nie. Pragmatyzm można na wiele sposobów pogodzić z ideą jakości duchowych. Nawet jego twórca uważał, że stanowisko to może obejmować idee spirytualistyczne: „O ile idee teologiczne okazuja się mieć wartość w życiu konkretnym, o tyle wedlug pragmatyzmu sa prawdziwe, prawdziwe w tym sensie, że sa $w$ tej mierze dobre". ${ }^{7}$ Zainteresowanego czytelnika odsyłam do książki Reinholda Niebuhra, ${ }^{8} \mathrm{w}$ której omawia on pragmatyczny wymiar takich idei w społeczeństwie.

Mimo że amerykański pragmatyzm początkowo był neutralny wobec idei religijnych i niereligijnych, $\mathrm{z}$ upływem lat $\mathrm{w}$ dużej mierze sprzymierzył się $\mathrm{z}$ pozytywizmem. „Wartość pieniężna” pozytywizmu zwykle utożsamiana jest ze skutkami operacyjnymi - to znaczy idea jest dobra, jeśli umożliwia przewidywanie przyszłości. Pragmatyzm zazwyczaj służy więc do wykluczania twierdzeń teologicznych na podobnych podstawach, co pozytywizm, lecz nie wygłasza żadnego metafizycznego twierdzenia na temat ich prawdziwości lub fałszywości.

Krótko mówiąc, pozytywizm i pragmatyzm są bardzo zbliżone w praktyce: pozytywizm postrzega twierdzenie nieoperacyjne jako „bezsensowne”, a pragmatyzm jako „bezużyteczne”.

Wziąwszy pod uwagę, że większość ludzi ma inklinacje religijne, ${ }^{9}$ a nawet że inklinacja religijna może być biologiczną cechą ludzi, ${ }^{10}$ byłoby zadziwiające, gdyby te filozofie wywierały szeroko zakrojony wpływ na ludzkie myślenie. Jednakże pewien ruch teologiczny powstały w dziewiętnastym wieku utorował

\footnotetext{
${ }^{7}$ William J AMES, Pragmatyzm. Nowe imię paru starych stylów myślenia, przeł. Michał Szczubiałka, Wydawnictwo KR, Warszawa 1998, s. 83 [wyróżnienia w oryginale].

${ }^{8}$ Por. Reinhold Niebuhr, The Irony of American History, Scribner, New York 1952.

${ }^{9}$ Por. Conrad Hackett and Brian J. Grim, „The Global Religious Landscape”, The Pew Forum on Religion and Public Life 18 December 2012, http://www.pewforum.org/2012/12/18/glo bal-religious-landscape-exec/ (08.08.2017).

${ }^{10}$ Por. Pascal Boyer, „Religion: Bound to Believe?”, Nature 2008, vol. 455, s. 1038-1039; Justin L. Barrett, Cognitive Science, Religion, and Theology: From Human Minds to Divine Minds, Templeton Press, West Conshohocken 2011.
} 
drogę ideom pozytywistycznym do środowisk ludzi o inklinacjach teologicznych.

Sferę duchową zawsze postrzegano jako tajemniczą z perspektywy ludzkiej. Być może da się nawiązać z nią kontakt, ale w dużej mierze uznaje się ją za niepojmowalną. W tym duchu w chrześcijańskiej wizji Boga przyznaje się, że drogi Boga nie zawsze są możliwe do zrozumienia przez człowieka. Na przykład w Księdze Izajasza 55:8-9 Bóg mówi ludziom: „Bo myśli moje nie są myślami waszymi ani wasze drogi moimi drogami - wyrocznia Pana. Bo jak niebiosa górują nad ziemią, tak drogi moje — nad waszymi drogami i myśli moje — nad myślami waszymi” (BT).

W historii myśli chrześcijańskiej uznawano to za stwierdzenie niekompletne. To znaczy do pewnego stopnia myśli i drogi Boga mogą być poznawalne, lecz ostatecznie znajdują się one ponad nami. Jednak ta idea, że drogi Boga są ponad naszymi, często wykorzystywana była jako „luk ratunkowy” przez osoby angażujące się w apologetykę. To znaczy, jeśli ktoś mówi, że „Bóg nie zezwoliłby na zajście X w świecie”, apologeta może odpowiedzieć, że „drogi Boga są ponad naszymi, jest więc możliwe, że Bóg miał dobry powód, by dopuścić do zajścia X w świecie". Problem polega na tym, że jeżeli dowolne pozytywne twierdzenie o teologii może uniknąć zakwestionowania po prostu dzięki uznaniu, że drogi Boga są ponad naszymi, to trudno zrozumieć, jak można by rozstrzygnąć jakikolwiek spór teologiczny.

Począwszy od dziewiętnastego wieku doktryna boskiej tajemniczości przeobraziła się w doktrynę niepojmowalności Boga, zgodnie z którą Bóg jest nie tylko tajemniczy, ale też nie istnieje obiektywny sposób poznania lub orzekania czegokolwiek o Bogu. Nic zatem, co mówimy o Bogu, nie może stanowić wiedzy. Pierwotnie chodziło jedynie o to, co ludzie mogą wiedzieć o Bogu, ale w końcu objęto w ten sposób wszystkie formy wiedzy duchowej. Dziś, gdy doktryna niepojmowalności Boga rzadko jest wyraźnie formułowana, można dostrzec ją w praktyce $\mathrm{w}$ tym, że społeczeństwo traktuje wiedzę teologiczną jako ze swej natury osobistą i niepodlegającą dyskusji. Twierdzenia teologiczne mają charakter osobisty, ponieważ - mimo że mogą być prawdziwe - nie istnieje sposób rozstrzygania między odmiennymi poglądami. Traktuje się je więc jako prywatne opinie, a nie jako przedmiot publicznego dyskursu. Przez wzgląd na doktrynę niepojmowalności Boga uznaje się je za nieobalalne i niepoznawalne. 
Podobnie każda indywidualna opinia teologiczna stawiana jest na równi, ponieważ wszystkie są w takim samym stopniu nieobalalne i niepoznawalne.

Te trzy nurty filozoficzne - filozofia mechanistyczna, pozytywizm/pragmatyzm oraz doktryna niepojmowalności Boga - wzajemnie się wspierają, chociaż żaden z nich nie pociąga za sobą drugiego. Filozofia mechanistyczna zapewnia ontologię świata (lub przynajmniej świata przyrody), który składa się wyłącznie z materii i ruchu. Pozytywizm i pragmatyzm ograniczają epistemologię jedynie do wielkości odpowiadających filozofii mechanistycznej. Z innej strony doktryna niepojmowalności Boga eliminuje idee teologiczne z dziedziny racjonalnego dyskursu, pozostawiając tylko kategorie stosowane w filozofii mechanistycznej.

Pozytywizm postrzega idee teologiczne jako bezsensowne, pragmatyzm jako nieprzydatne, a filozofia mechanistyczna jako nieprawdziwe. Zgodnie $\mathrm{z}$ doktryną niepojmowalności Boga idee teologiczne są prawdziwe, ale niepoznawalne. Zasadniczo w ten sposób otrzymujemy po prostu filozofię mechanistyczną. Chociaż doktryna niepojmowalności Boga zwykle zakłada (w przeciwieństwie do filozofii mechanistycznej), że świat ma rzeczywisty aspekt duchowy, to fakt, że nie można wypowiadać żadnych definitywnych twierdzeń o Bogu lub sferze duchowej, jest dość dogodny i możliwy do przyjęcia przez zwolenników filozofii mechanistycznej. Doktryna niepojmowalności Boga bardziej zbliża też pragmatyzm do filozofii mechanistycznej. Jak zauważyłem wcześniej, możliwe jest formułowanie pragmatycznych twierdzeń teologicznych. Jednak doktryna niepojmowalności Boga zniechęca do tego, ponieważ apriorycznie każe uznać, że nie mają one „wartości pieniężnej”. Mimo że pragmatyzm nie wysuwa definitywnych twierdzeń o naturze świata, bardzo dobrze licuje on z filozofią mechanistyczną.

A więc mimo iż te filozofie są w dużej mierze niezależne od siebie nawzajem, współistnieją one w dogodnej, umożliwiającej wzajemne wspieranie się przestrzeni. Innymi słowy, uprzedzenia nieodłącznie związane z tymi filozofiami są spójne ze sobą i wzajemnie się wspierają. 


\section{Identyfikacja tych nurtów filozofii w oświadczeniach NSTA}

Ustaliliśmy dotąd, że filozofia mechanistyczna, pozytywizm/pragmatyzm oraz doktryna niepojmowalności Boga wzajemnie się wspierają. Pojawia się więc pytanie, jak ta trójca ma się do naturalizmu metodologicznego? Każdą $\mathrm{z}$ tych filozofii można łatwo wydobyć z samych oświadczeń NSTA.

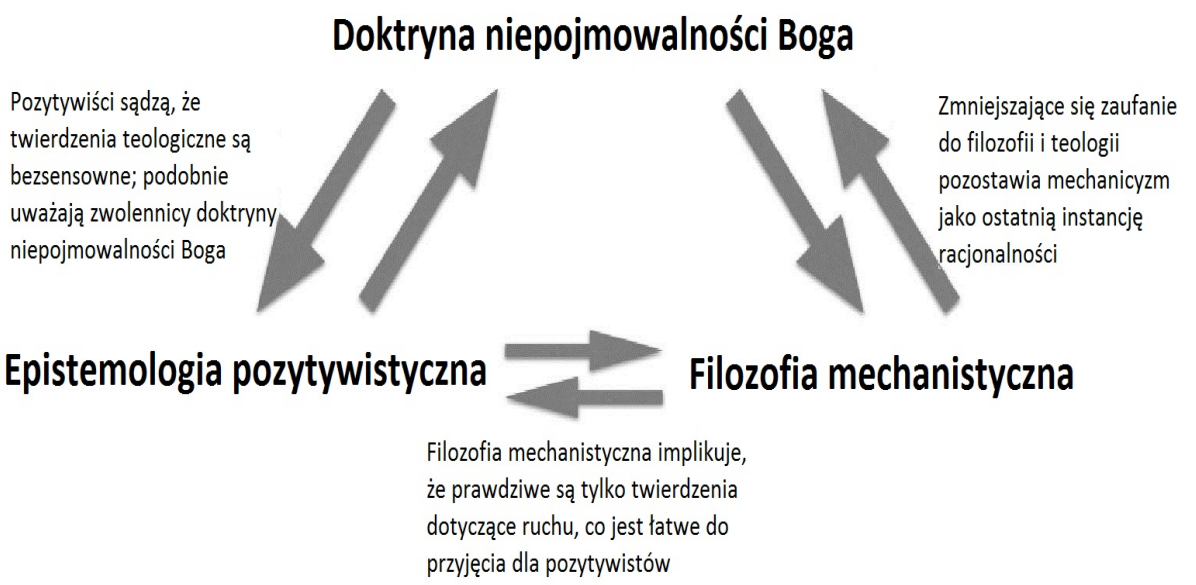

Rys. 1. Schemat wzajemnego wspierania się trzech nurtów filozofii stojących za naturalizmem metodologicznym.

Wyjściowym założeniem oświadczenia jest to, że nauka „zakłada, że Wszechświat funkcjonuje na podstawie prawidłowości, które możemy zrozumieć dzięki systematycznym badaniom”. Przede wszystkim przyjmuje się tu założenie, że Wszechświat funkcjonuje na podstawie prawidłowości. Można byłoby powiedzieć, że niektóre części Wszechświata funkcjonują na podstawie prawidłowości, ale tutaj mamy ogólne twierdzenie o Wszechświecie. Jest to całkowicie zgodne z filozofią mechanistyczną.

Zauważmy następnie, że nie ma mowy o tym, iż możemy zrozumieć niektóre $\mathrm{z}$ tych prawidłowości lub ich podzbiór, lecz po prostu, że możemy je zrozumieć. Epistemologia również jest więc ograniczona do tego, co głosi filozofia mechanistyczna. W oświadczeniu NSTA pojawia się ponadto stwierdzenie, że w nauce hipotezy testowane są w odniesieniu do danych empirycznych (to jest 
materii i ruchu), co wywodzi się z pozytywistycznego/pragmatystycznego poglądu na rzeczywistość.

Wreszcie, oświadczenie odnosi się do wyjaśnień religijnych. Mówi, że „nauka zajmuje się wyjaśnianiem świata przyrody wyłącznie za pomocą procesów naturalnych, więc nie może odwoływać się do przyczynowości nadnaturalnej w swoich wyjaśnieniach". Twierdzenie to nigdy nie jest jednak uzasadniane. Co takiego jest $\mathrm{w}$ naturze świata, że zachodzące $\mathrm{w}$ nim prawidłowości nie mogą mieć przyczyny nadnaturalnej? Istnieją tylko dwa możliwe wyjaśnienia: albo jest to jedynie rozróżnienie związane z przedmiotem badań, albo chodzi o to, że poważni zwolennicy tego poglądu uznają, iż filozofia mechanistyczna oferuje prawdziwy obraz rzeczywistości.

Zacznijmy od rozważenia możliwości, że jest to jedynie rozróżnienie związane z przedmiotem badań, czyli że nauka nie zajmuje się przyczynami nadnaturalnymi, ponieważ przedmiotem jej zainteresowania są przyczyny naturalne. Niektórych ludzi mogą interesować przyczyny nienaturalne, ale nie te przyczyny postanowili oni badać. W świetle tego poglądu operacyjne kryterium demarkacji i metodologie wywodzą się w sposób naturalny $\mathrm{z}$ istoty przedmiotu badań. ${ }^{11}$ Analiza struktury oświadczenia NSTA nasuwa jednak wniosek, że jest tam mowa o całym zakresie możliwych przyczyn, a nie tylko o ich podzbiorze.

Ponadto ograniczenia związane z przedmiotem badań nigdy nie przybierają postaci absolutnych zakazów. Gdybym na przykład powiedział, że badania Renesansu ograniczają się do okresu od wieku czternastego do siedemnastego, to nie potępiano by artykułu omawiającego trzynastowiecznych prekursorów Renesansu lub wpływ tej epoki na wiek osiemnasty i późniejsze, czy też nawet częściowe pokrywanie się myśli renesansowej z poglądami jej prekursorów i następców. Nie dochodziłoby do procesów sądowych mających na celu wykorzystanie sądów do zakazania wprowadzania takich idei do badań Renesansu.

Gdyby ograniczenie to dotyczyło wyłącznie przedmiotu badań, to trudno byłoby zrozumieć, dlaczego ktokolwiek mógłby mieć zastrzeżenia do ludzi zacierających granice, znajdujących punkty pokrywania się idei lub wskazujących inne rodzaje aktywności zmierzającej do integrowania przyczyn naukowych

\footnotetext{
${ }^{11}$ Por. Alexander SicH, „The Independence and Proper Roles of Metaphysics in Support of an Integrated Understanding of God's Creation", w: Bartlett, Halsmer, and Hall (eds.), Engineering and the Ultimate..., s. 39-62.
} 
i nienaukowych. Co więcej, aby ograniczenie związane z przedmiotem badań miało sens, należałoby też zapewnić sposoby rozróżniania między przyczyną należącą do dziedziny nauki a taką, która wykracza poza jej zakres. Autorzy oświadczenia NSTA takiego rozróżnienia nie dostarczają i w związku z tym wydaje się, że nie wierzą oni w istnienie takiej przyczyny.

Dodatkowo w oświadczeniu czytamy, że „nauka nie może formułować twierdzeń o siłach nadnaturalnych, ponieważ wykraczają one poza zakres jej kompetencji”. Również w tym przypadku wydaje się, że autorzy, nie podając sposobu rozróżniania między nauką a nadnaturalizmem, sądzą, iż żadne prawidłowości i nic, co podlega ścisłym badaniom, nie mają i nie mogą mieć czegokolwiek wspólnego z tym, co nadnaturalne. Ma to sens jedynie na gruncie doktryny niepojmowalności Boga. Czy gdyby we Wszechświecie działały przyczyny nadnaturalne, a jakiś naukowiec wnikliwie zbadał przyczynę, o której nie wiedział jeszcze, że jest nadnaturalna, to co ów naukowiec miałby zrobić w myśl oświadczenia NSTA? Zniszczyć zgromadzone przez siebie dane? Spalić swoje książki? Przeprosić za wybranie niewłaściwego przedmiotu badań? Nie, a to dlatego, że w oświadczeniu najwyraźniej po prostu zakłada się, że każde ścisłe badanie poznawalnego świata doprowadzi wyłącznie do odkrycia przyczyn o charakterze naturalistycznym. Wskazuje to, że albo przyczyny naturalistyczne są jedynymi dostępnymi, albo że — przyjmując doktrynę niepojmowalności Boga — są jedynymi poznawalnymi przyczynami.

Wreszcie, w oświadczeniu stwierdza się, że „Nauka doprowadziła do wzrostu naszej wiedzy właśnie dlatego, że kładzie nacisk na poszukiwanie przyczyn naturalnych". W świecie interdyscyplinarnej współpracy dziwne wydaje się przekonanie, że tylko nauka czerpie korzyści z jakiegoś zaściankowego poglądu na wiedzę. Ten zaściankowy pogląd może być sensowny wyłącznie wówczas, jeśli jego zwolennicy uważają go za jedyną możliwość.

Mimo że w oświadczeniu nie ma jawnego odniesienia do filozofii mechanistycznej, pozytywizmu/pragmatyzmu czy do doktryny niepojmowalności Boga, wpływ tych filozofii łatwo można dostrzec. Aby więc sprawdzić, czy podstawa tego rozumowania jest prawidłowa, musimy przyjrzeć się każdej z tych filozofii, by przekonać się z kolei, czy są one słuszne zarówno w sobie, jak i z siebie, a także, czy ich ścisłe stosowanie wspomaga rozwój nauki. Nie podejmę próby odpowiedzi na pytanie, czy filozofie te są pomocne $\mathrm{w}$ indywidualnych przypadkach (uważam bowiem, że rzeczywiście tak jest), lecz postaram się jedynie usta- 
lić, czy ścisłe ich przestrzeganie, jak również przestrzeganie reguł wyłożonych w oświadczeniu NSTA, może mieć negatywny wpływ na rozwój nauki.

\section{Filozofia mechanistyczna}

Ontologią, która daje temu wszystkiemu podstawę, jest filozofia mechanistyczna - idea, że cała przyroda, w tym nasze umysły, jest wytworem sił mechanicznych.

\subsection{Filozofia mechanistyczna w siedemnastym wieku}

Filozofia mechanistyczna powstała jako alternatywa dla scholastycznych, arystotelesowskich poglądów na przyrodę, które definiowały rzeczy w kategoriach substancji i jakości. Zwolennicy filozofii mechanistycznej czuli, że wyjaśnienia arystotelesowskie $\mathrm{w}$ istocie nie wyjaśniają, a więc i nie dążą do wyjaśniania, przyrody w sposób zapewniający głębsze wyjaśnienia przyczynowe. Podczas gdy filozofia arystotelesowska była filozofią całości, filozofia mechanistyczna koncentrowała się na rozkładaniu rzeczy na części i ustalaniu, jak te części działają. Filozofia arystotelesowska skupiała się na bytach, ich istotach i własnościach, zaś przedmiotem zainteresowania filozofii mechanistycznej było współdziałanie składników bytów, dzięki któremu takie istoty i własności mogą funkcjonować.

Samo to nie prowadziło jeszcze do różnic ontologicznych. Tym, co sprawiało, że filozofia mechanistyczna była tak odmienna, był jej cel ujęcia wszystkiego w kategoriach przyczyn materialnych i sprawczych, a także nierespektowanie żadnej formy przyczynowości niematerialnej.

Niezależnie od tego, czy to filozofia prawdziwa, na pierwszy rzut oka wydaje się ona prosta. Problem pojawia się jednak, gdy chcemy ustalić, co naprawdę znaczy „przyczyna materialna”. Problem zdefiniowania przyczyn materialnych prześladował filozofię mechanistyczną od samego początku. W istocie część tego, co obecnie postrzega się jako wielkie osiągnięcia filozofii mechanistycznej, w tamtym czasie wyraźnie przeczyło tej filozofii.

Siedemnastowieczna filozofia mechanistyczna, na przykład, nie była jednolita, ale na ogół głosiła następujące poglądy: 
Atomistyczny korpuskularyzm, czyli pogląd, że podstawą przyrody, w jej istocie, jest geometria maleńkich, nieprzenikliwych cząstek i ich oddziaływania. Niektórzy uznawali, że te cząstki są sztywne, ale inni sądzili, że cechują się pewną miarą plastyczności. Różnie ukształtowane atomy tworzyły różne rodzaje substancji i oddziaływań.

Koncepcja lokalności, to jest pogląd, zgodnie z którym zmiana może mieć wyłącznie charakter lokalny. Aby więc jedna cząstka mogła oddziałać na inną, musi się z nią stykać. Działanie na odległość postrzegane jest jako duchowy typ przyczynowości.

Gradualizm, a więc pogląd, że w przyrodzie nie zachodzą nagłe zmiany. Wszystko musi przejść łagodny ciąg kroków. W istocie kryteria te stanowią jeden z powodów, dla których niektórzy uważali, że atomy są plastyczne całkowicie sztywny atom, który odbiłby się od innego, musiałby zmienić kierunek w sposób nagły. Plastyczność atomów umożliwiała utrzymanie zarówno atomizmu, jak i gradualizmu.

Pasywizm, czyli idea, że zmiany przydarzają się atomom. Znaczy to, że atomy po prostu „są", a ich geometria wpływa na ich wzajemne oddziaływania. Atomy są zasadniczo bierne i nie wywierają aktywnego wpływu na otaczający je świat.

Poglądy te stanowiły podstawę siedemnastowiecznej filozofii mechanistycznej. Zauważmy, że nie tylko opisują one siedemnastowieczną fizykę, lecz są związane z filozofią mechanistyczną rozwijaną w tamtym czasie. Atomy były bierne, ale nie dlatego, że ustalono to eksperymentalnie, lecz z tej racji, że filozofia mechanistyczna dopuszczała jedynie przekonanie, iż na oddziaływania fizyczne wpływ wywiera geometria. Świat składał się z atomów, ponieważ byty wyższego poziomu, opisywane przez scholastyków, były zbyt duchowe. Przyczynowość miała charakter lokalny, gdyż postulując działanie na odległość, należało zakładać, że istnieje jakaś cecha materii, która wykracza poza geometrię — a więc przyjmować założenie zgodne ze scholastycznym poglądem na świat.

Co zaskakujące, największy postęp w siedemnastowiecznej fizyce nie miał nic wspólnego z filozofią mechanistyczną, lecz z fizyką newtonowską, która zrywała z niemal każdym aspektem filozofii mechanistycznej. Większa część pracy Newtona bazowała na idei grawitacji, która była znacznie bardziej scholastyczna niż mechanistyczna. 
Przede wszystkim grawitacja to siła wrodzona, własność obiektu — nie zaś skutek geometrii obiektu. Jako własność, grawitacja przywodzi na myśl scholastyczne sposoby myślenia, zgodnie z którymi przyroda składa się z substancji, sił, istot i jakości. Po drugie, grawitacja działa na odległość. Przed Newtonem zdolność działania na odległość była zarezerwowana dla bytów i sił duchowych. Wreszcie, dzięki grawitacji obiekty są w fizyce czynnikami aktywnymi, a nie biernymi. Obiekty same, za sprawą swej natury, działają siłami na otaczające je rzeczy. Nie są bierne, jak wymaga tego filozofia mechanistyczna.

Tak więc fizyka newtonowska, mimo że wielu ludzi uznaje ją współcześnie za triumf mechanicyzmu nad religijnymi poglądami na świat, w swoich czasach była $\mathrm{w}$ istocie czymś przeciwnym. Newton sprzeniewierzał się naturalizmowi metodologicznemu, przypisując przyrodzie jakości, które zarezerwowane były wcześniej dla istot i sił duchowych. To właśnie było najczęstszym przedmiotem krytyki w momencie ogłoszenia fizyki newtonowskiej.

Jednym z takich krytyków był Gottfried Leibniz:

Zjawiskiem nadnaturalnym jest także to, że ciała przyciągają się z daleka bez żadnego pośrednictwa, oraz to, że ciało porusza się po linii kolistej zamiast oddalić się po stycznej, choć nic nie przeszkadza, aby się w ten sposób oddaliło. Jako że zjawiska te wcale nie dają się wyttumaczyć natura rzeczy. ${ }^{12}$

Jak widać, Leibniz, współtwórca rachunku różniczkowego, krytykował Newtona za postulowanie sił nadnaturalnych i nawet jeszcze mocniej podkreślił, że siły te mają charakter nienaturalny. Niektórzy, jak Einstein, zaproponowali bardziej lokalne wersje mechaniki newtonowskiej, które nie były narażone na argumenty krytyczne Leibniza. Pytanie jednak brzmi: co Newton miałby począć ze swoimi rozważaniami? Czy powinien był je porzucić, skoro nie spełniały naturalistycznych oczekiwań jego czasów? Czy powinien był czekać do momentu, gdy byłby już w stanie opracować naturalistyczną ich wersję? Jeśli nie, to na jakiej podstawie można by dzisiaj dopuszczać, by naturalistyczne oczekiwania względem przyrody utrudniały badania? Przykład Newtona pokazuje, że stano-

\footnotetext{
${ }^{12}$ Gottfried Wilhelm LeIBNIz, „Polemika z Clarke’iem. Czwarte pismo Leibniza”, w: Gottfried Wilhelm LeibNIz, Wyznanie wiary filozofa, rozprawa metafizyczna, monadologia, zasady natury i laski oraz inne pisma filozoficzne, przeł. Stanisław Cichowicz, Juliusz Domański, Henryk Krzeczkowski i Henryk Moese, Biblioteka Klasyków Filozofii, Państwowe Wydawnictwo Naukowe, Warszawa 1969, s. 354 [346-354] [wyróżnienia dodane].
} 
wisko, które w jednym okresie uznawane jest za niemechanistyczne, w innym czasie postrzegane jest jako uosobienie mechanicyzmu.

\subsection{Filozofia mechanistyczna w dziewiętnastym wieku}

Jak zauważyłem wyżej, ustalenie, czym jest filozofia mechanistyczna, stanowi nie lada problem. Po sukcesie fizyki newtonowskiej trzeba było wymyślić nową filozofię mechanistyczną, która obejmowałaby perspektywę newtonowską. W związku z tym w wieku dziewiętnastym kluczowymi aspektami nowej filozofii mechanistycznej były:

Przyczynowe domknięcie przyrody, to jest teza, zgodnie z którą poza przyrodą nie istnieje nic, co wpływałoby na zjawiska przyrodnicze. Przyrodą rządzą niezmienne prawa, a kiedy znane są zarówno prawa, jak i aktualny stan świata, to wszystko wiadomo o przyczynach, które wywołają kolejne ciągi skutków.

Determinizm głoszący, że — biorąc pod uwagę przyczynowe domknięcie przyrody - jeśli znane są wszystkie siły działające w przyrodzie, to poznawalne są również ich skutki (tak mówi teoria, ale nikt nie wierzy, że jest to możliwe w praktyce). Ponieważ aktualne skutki są przyczynami kolejnego zespołu skutków, więc teoretycznie cykl przyczynowo-skutkowy może być prześledzony do dowolnego momentu przyszłości. W związku z tym na podstawie aktualnego stanu świata można, w zasadzie, określić wszystkie przyszłe skutki.

Materiocentryzm związany z przekonaniem, że jednym z celów filozofii mechanistycznej jest wyeliminowanie przyczynowości duchowej z przyrody, przez co podstawowym przedmiotem zainteresowania tej filozofii jest materia.

Tę nową filozofię mechanistyczną najlepiej podsumował matematyk Pierre Laplace:

Obecny stan Wszechświata możemy postrzegać jako skutek przeszłości i przyczynę przyszłości. Intelekt, który w dowolnej chwili znałby wszystkie siły działające w przyrodzie oraz wzajemne położenie składających się na nią bytów i który byłby na tyle potężny, by poddać te dane analizie, mógłby $w$ jednym wzorze zawrzeć ruch zarówno największych ciał we Wszechświecie, jak i najmniejszego atomu. Dla takiego intelektu 
nic nie byłoby niepewne, a przyszłość jawiłaby mu się równie wyraźnie, jak przeszłość. ${ }^{13}$

Ta nowa filozofia mechanistyczna wydawała się mocna i onieśmielająca. Jednakże na początku dwudziestego wieku nowe przełomowe odkrycia w fizyce doprowadziły do upadku również tej odmiany filozofii mechanistycznej. Wraz z powstaniem mechaniki kwantowej okazało się, że wszystkie opisy fizyczne są cząstkowe i niepełne. Mechanika kwantowa jest nie tylko niekompletna, ale eksperymentalnie wykazano też, że losowość (to jest niemożliwość pełnego opisu przyczynowości w kategoriach jej obecnego stanu) stanowi fundament fizyki. Podważa to zarówno koncepcję przyczynowego domknięcia przyrody, jak i determinizm.

Mechanika kwantowa oddaliła nas też od fizyki materiocentrycznej. Dualizm korpuskularno-falowy w fizyce kwantowej prowadzi do tego, że materiocentryczna filozofia przyrody jest $\mathrm{z}$ konieczności niekompletna. W niektórych nurtach mechaniki kwantowej (takich jak szkoła kopenhaska) to wręcz sam umysł stanowi podstawowy byt.

Wreszcie, jedyny aspekt siedemnastowiecznej filozofii mechanistycznej, któremu nie zaprzeczył Newton, czyli gradualizm, został podważony przez mechanikę kwantową, zgodnie z którą przyczynowość może zachodzić i zachodzi skokowo.

Po raz drugi więc rozwój fizyki nie spełniał oczekiwań filozofii mechanistycznej i naturalizmu. Chociaż naturalizm niewątpliwie skutecznie dostosował się do sytuacji tak, aby znalazło się w jego ramach miejsce na wszystkie te odkrycia w fizyce, to trudno argumentować, że w jakikolwiek sposób wspomógł on rozwój fizyki, może poza tym, że posłużył jako środek do kodyfikacji założeń danej epoki, które wymagały krytyki. Na pewno nie należy uznawać, że na-

\footnotetext{
${ }^{13}$ Pierre Simon de Laplace, A Philosophical Essay on Probabilities, trans. Frederick Wilson Truscott and Frederick Lincoln Emory, John Wiley \& Sons, London 1902 (1814), s. 4, http:// bayes.wustl.edu/Manual/laplace_A_philosophical_essay_on_probabilities.pdf (15.11.2017).

(Przyp. tłum.) Podana tu wersja książki Laplace'a zawiera nieco inny przekład na język angielski niż ten przytoczony w artykule będącym podstawą niniejszego przekładu, jednak polskie thumaczenie wypowiedzi Laplace'a wykonano tutaj na podstawie cytatu zamieszczonego w artykule Bartletta.
} 
uka powinna narzucać sobie ograniczenia, biorąc za podstawę konkretny pogląd danego czasu na to, czym jest wyjaśnienie naturalistyczne.

\subsection{Wspólczesna filozofia mechanistyczna}

W każdej kolejnej odmianie filozofia mechanistyczna stawała się znacznie słabsza jako teza o rzeczywistości. Siedemnastowieczna filozofia mechanistyczna głosiła dość jednoznaczne twierdzenia o tym, co według niej zawiera w sobie lub czego nie zawiera pojęcie „mechanizmu”. Mimo że filozofia ta okazała się w dużej mierze błędnym poglądem na świat, możemy przynajmniej docenić ją jako próbę dostarczenia zrozumiałego opisu funkcjonowania świata.

Przedmiotem zainteresowania dziewiętnastowiecznej filozofii mechanistycznej nie był ostateczny opis świata, lecz ogólny model wzajemnego oddziaływania przyczyn i skutków w ramach jakiegokolwiek odpowiedniego opisu świata. Innymi słowy, nie wypowiadano się na temat tego, jakie powinny być konkretne prawa fizyki, lecz skupiono się na związku między prawami a zjawiskami rządzonymi przez te prawa.

We współczesnym wcieleniu filozofii mechanistycznej za mechanizm uznaje się wszystko, co:

- Stanowi odrębne zjawiska

- Złożone jest z części

- Ma części o określonej strukturze

- Ma części wchodzące w jakąś formę związku przyczynowego z innymi częściami

Chociaż prawdopodobnie nie ma nic złego w tej odmianie filozofii mechanistycznej jako takiej, to trudno dostrzec, co, o ile cokolwiek, ma na do powiedzenia uczonemu badającemu jakieś zjawisko. Nawet badacz zjawisk paranormalnych (duchów, chochlików i tym podobnych) byłby w stanie wpasować swoje badania $\mathrm{w}$ ramy tak zdefiniowanego mechanizmu. $\mathrm{W}$ istocie trudno wyobrazić sobie jakikolwiek opis zdarzeń, które nie byłyby spójne z tą formą „mechanizmu”. Jeżeli tylko tyle ma się na myśli pod pojęciem „zjawisk przyrodniczych”, to pojawia się problem ze zrozumieniem, co usiłuje się wykluczyć w oświadczeniach NSTA. 
Jeśli zatem w oświadczeniach NSTA podejmuje się próbę opisania czegoś za pomocą terminu ,zjawiska przyrodnicze”, to trudno pojąć, co jest przez to rozumiane. Termin ten zwykle używany jest tak, by obejmował treści filozofii mechanistycznej, ale - jak się przekonaliśmy - filozofia mechanistyczna wielokrotnie okazywała się fałszywa lub, w swym współczesnym wcieleniu, jest zupełnie bezużyteczna jako środek odróżniania zjawisk. Jak natomiast pokazuje historia filozofii mechanistycznej, wygląda na to, że pojęcie „zjawisk przyrodniczych" to jedynie wyraz uprzedzeń danej epoki, które raczej wstrzymują rozwój nauki zamiast mu sprzyjać.

Innym możliwym we współczesnej epoce znaczeniem terminu „zjawiska przyrodnicze", które ma bardziej określoną strukturę, jest komputacjonizm, wyrażony w sformułowanej przez Stephena Wolframa Zasadzie Równoważności Obliczeniowej ${ }^{14} \mathrm{i}$ w innych podobnych zasadach, takich jak Teza Wykonalnego Poznania. ${ }^{15}$ Za tymi zasadami kryje się idea, że ograniczenia przyrody są takie same jak ograniczenia obliczeniowe. Zgodnie z tą filozofia ,zjawisko przyrodnicze" to takie, które jest obliczalne przy użyciu urządzenia w rodzaju maszyny Turinga.

Podobnie jak poprzednie odmiany filozofii mechanistycznej, ten pogląd także służy do zwięzłego wyrażenia uprzedzeń współczesnej epoki, które należy raczej przezwyciężyć niż uznać za prawdziwy opis stanu świata. W niniejszym artykule nie zostanie przedstawiona wyczerpująca krytyka tego poglądu, ale czytelnik może zapoznać się z nią w innych publikacjach. ${ }^{16}$

\section{Pozytywizm i pragmatyzm}

Mimo że filozofia mechanistyczna jest nie do utrzymania jako ontologiczna

\footnotetext{
${ }^{14}$ Por. Stephen Wolfram, A New Kind of Science, Wolfram Media 2002.

${ }^{15}$ Por. Iris van RooIJ, „The Tractable Cognition Thesis”, Cognitive Science: A Multidisciplinary Journal 2008, vol. 32, no. 6, s. 939-984, http://onlinelibrary.wiley.com/doi/10.1080/03640 210801897856/pdf (16.11.2017).

${ }^{16}$ Por. Jonathan Bartlett, „Using Turing Oracles in Cognitive Models of Problem-Solving”, w: Bartlett, Halsmer, and Hall (eds.), Engineering and the Ultimate..., s. 99-122; Jonathan BARTLETT, „Describable But Not Predictable: Mathematical Modeling and Non-Naturalistic Causation", w: Bartlett and Holloway (eds.), Naturalism and Its Alternatives in Scientific Methodologies..., s. 113-127.
} 
podstawa naturalizmu metodologicznego, niekoniecznie prowadzi to do unieważnienia pozytywistycznej/pragmatystycznej epistemologii. Jest na przykład możliwe, że nawet jeśli szczegółowe teorie świata nie muszą być zależne od filozofii mechanistycznej, to nasza wiedza o nich może być ograniczona do operacyjnych sposobów, w jakie te teorie wywierają wpływ na nasze doświadczenie.

Jak zauważyłem wcześniej, w zależności od tego, jakie ktoś stawia sobie cele, można sformułować pragmatyzm w taki sposób, aby znajdował się poza domeną pozytywizmu. Często łączony jest on z pozytywistycznym ujęciem świata, ale nie ma tu mowy o koniecznej równoważności. Ponadto, jeżeli czyimś celem w nauce jest odkrywanie rzeczywistości, to pragmatyzm nie jest w tym względzie odpowiednią epistemologią. Pragmatyzm często służy jako epistemologia „kompromisowa” czy „zastępcza”. Jest tak wówczas, gdy biorąc pod uwagę status ontologiczny jakiegoś twierdzenia, można odwołać się do pragmatycznej wartości twierdzenia, nawet jeśli jego status ontologiczny jest wielce wątpliwy.

W takim wypadku jedynym ujęciem epistemologii, które stanowiłoby podstawę dla ściśle ekskluzjonistycznego stanowiska naturalizmu metodologicznego, byłby pozytywizm. Pojawia się więc pytanie, czy pozytywizm może dać normatywna podstawę epistemologii naukowej dla całej sfery badań nad przyczynowością we Wszechświecie.

Niewykluczone, że w zawężonym układzie odniesienia pozytywizm może być wartościową epistemologią, podobnie jak naturalizm może być wartościową ontologią dla pewnych aspektów świata. Jednak w skład nauki, w jej dzisiejszej praktyce, nie wchodzi tylko fizyka, ale też biologia, psychologia, ewolucjonizm, kosmologia i inne. Kosmologia i ewolucjonizm, jako totalne ujęcia historii kosmosu, wymagają również totalnych ujęć przyczynowości, aby móc dostarczyć właściwego opisu swych przedmiotów badań. Aby więc epistemologia była normatywna dla nauki w ogóle, nie zaś dla jakiejś nauki szczegółowej, musi mieć uniwersalną stosowalność. Przekonamy się jednak, że pozytywizm nie jest adekwatną epistemologią totalną.

Fundamentalny problem polega na tym, że pozytywizm jest stanowiskiem samoobalającym się. Pozytywizm głosi, że wszystkie sensowne twierdzenia należy definiować wyłącznie operacyjnie (to znaczy w kategoriach wyników em- 
pirycznie weryfikowalnych) lub muszą być one prawdziwe a priori (czyli być twierdzeniami matematycznymi). Tego pozytywistycznego twierdzenia także nie można jednak zdefiniować w kategoriach wyników weryfikowalnych empirycznie i nie jest ono prawdziwe a priori. Gdyby zatem pozytywizm był prawdziwy, sam by się obalił jako stanowisko bezsensowne. Już samo to powinno uniemożliwić uznanie go za epistemologię totalną.

Mimo to, z powodów niezrozumiałych dla autora, niektórzy nie sądzą, że samoobalalność (powszechny problem epistemologii sceptycznych) unieważnia dane stanowisko filozoficzne. Dlatego wskażę dodatkowe problemy trapiące poglądy pozytywistyczne.

Pierwszy problem dla pozytywizmu stanowi Quine'owska koncepcja względności ontologicznej. Quine wskazuje, że wszystkie twierdzenia, także empiryczne, są częścią większej sieci struktur przekonaniowych. Aby móc więc głosić twierdzenia empiryczne, musimy uprzednio dysponować strukturami przekonaniowymi, które nie są empiryczne, ale umożliwiają dokonywanie pomiarów. Jak wykazał Norwood Russell Hanson, wszystkie pomiary empiryczne opierają się na modelach. Skoro te modele i struktury przekonaniowe stanowią podstawę naszych pomiarów, to pomiary będą prawidłowe o tyle, o ile słuszne są modele i struktury przekonaniowe, od których pomiary są zależne. Jeśli więc wyniki empiryczne mają być sensowne, to sensowne muszą być także nieempiryczne modele, na których te wyniki się opierają.

Drugi problem dla pozytywizmu związany jest $\mathrm{z}$ tezą Gödla o niezupełności, zgodnie z którą istnieją prawdziwe, poznawalne fakty, które nie są weryfikowalne na podstawie jakiegoś ustalonego zbioru aksjomatów. Jedynymi dopuszczalnymi w pozytywizmie wyjątkami od prawd weryfikowalnych empirycznie są aprioryczne prawdy, których dostarcza na przykład matematyka. Teza o niezupełności wprowadza jednak nowy zbiór prawd matematycznych, które opieraja się na matematyce, ale nie są weryfikowalne na podstawie aksjomatów matematycznych i nie są weryfikowalne empirycznie. Przynajmniej niektóre $\mathrm{z}$ tych prawd są poznawalne. Istnieją zatem rzeczywiste, ważne prawdy, które nie są weryfikowalne w sposób, o jakim mówi pozytywizm.

Po trzecie, podobne problemy dotyczą wiedzy niematematycznej. Jak wskazuje Alvin Plantinga, w życiu pełno jest rzeczywistych, lecz nieweryfikowalnych prawd. Na przykład nie można zweryfikować istnienia świadomości in- 
nych umysłów. Jej istnienie jest przez nas zakładane, ale nie da się tego zweryfikować w jakiś niezależny sposób. Można argumentować, że mamy biologiczną (a więc a priori) podstawę dla takich przekonań, lecz oznaczałoby to, że mamy także biologiczną podstawę dla wiary w Boga i w inne istoty duchowe. Jeśli zatem pozytywizm włącza podstawy biologiczne do zbioru wiedzy apriorycznej, który może mieć zastosowanie w nauce, to nie można na tej podstawie wykluczać wyjaśnień nadnaturalistycznych.

Pozytywizm i pragmatyzm nie są jednak zupełnie puste jako epistemologie. Jedna jakość, którą podkreślają i która warta jest zachowania, to wzajemne powiązanie prawd. Pozytywizm, łącząc całą wiedzę z działaniem operacyjnym, zmusza do tego, aby wiedza była przynajmniej z czymś powiązana. Rzeczywiście pomaga to w eliminacji pozbawionych sensu prawd, które nie mają żadnego związku z rzeczywistością. Problem polega jednak na tym, że zakładanie, iż wszystko musi być powiązane w pewien sposób z konkretnym zbiorem prawd, nadmiernie ogranicza wiedzę i znaczenie.

\section{Doktryna niepojmowalności Boga}

Jak zasugerowałem wcześniej, doktryna niepojmowalności Boga to podejście do idei teologicznych głoszące, że wiedza teologiczna jest nadracjonalna. Czasem doktryna ta łączona jest $\mathrm{z}$ poglądem, zgodnie $\mathrm{z}$ którym pewne aspekty Boga nie są dla nas pojmowalne. ${ }^{17} \mathrm{Tu}$ odnoszę się jednak do ruchu, który nabrał impetu w dziewiętnastym wieku i głosi mocniejszą tezę, że nic na temat Boga (być może poza jego istnieniem) nie jest pojmowalne. Skoro drogi Boga są ponad nami, a natura Boga znajduje się ponad naszą naturą, to nie da się uzyskać żadnej rzeczywistej wiedzy o Bogu lub o jakimkolwiek aspekcie sfery nadnaturalnej. Ściśle rzecz biorąc, doktryna niepojmowalności Boga ogranicza się do wiedzy o Bogu, lecz zwykle, jak wykażę, jest też stosowana do każdej wiedzy teologicznej czy niematerialnej.

Można zapytać, jaka teologia motywowała wczesny rozwój empiryzmu w nauce. Za fundament empiryzmu często uznawany jest woluntaryzm, czyli pogląd, że Bóg stworzył świat w sposób wolny, to znaczy zgodnie ze swoim wy-

\footnotetext{
${ }^{17}$ Por. Richard C. Sproul, „Divine Incomprehensibility”, Tabletalk Magazine August 2014, https://tabletalkmagazine.com/article/2014/08/divine-incomprehensibility/ (22.11.2017).
} 
borem, a nie pod przymusem. ${ }^{18}$ Ponieważ wybór aktu stworzenia był wolnym wyborem Boga, więc to, co stworzył, również było wolnym wyborem i dlatego nie można tego wydedukować $\mathrm{z}$ wiedzy apriorycznej. Musimy natomiast zwrócić oczy w stronę świata i zbadać go, aby dowiedzieć się, co Bóg zechciał stworzyć. Peter Harrison stwierdził, ${ }^{19}$ że wcześni empiryści przyjmowali słabszą odmianę doktryny niepojmowalności Boga. Skoro naukowcy nie mogą poznać myśli Boga, to muszą odkrywać, jaki jest świat, wykorzystując metodę empiryczną. Chociaż w tamtym okresie historii naukowcy byli sceptyczni co do apriorycznej wiedzy o zamiarach Boga, to nie mieli takiego stosunku do swej zdolności poznania zamiarów Boga na podstawie badań empirycznych.

Jednak w dziewiętnastym wieku doktryna niepojmowalności Boga zaczęła rozpowszechniać się w kręgach akademickich, a jej wpływ utorował drogę współczesnym poglądom na naturalizm metodologiczny.

Można to dostrzec na przykład w modyfikacjach, jakie Karol Darwin wprowadzał do książki O powstawaniu gatunków w różnych jej wydaniach. Darwin ciągle korygował tę książkę w odpowiedzi na krytykę. Korekty te mogą pomóc zrozumieć, jak Darwin uzasadniał swoje metody i wnioskowania. Stephen Dilley ${ }^{20}$ skatalogował zmiany wprowadzone do $\mathbf{O}$ powstawaniu gatunków dotyczące naturalizmu metodologicznego (choć Darwin tą nazwą się nie posługiwał) i ich uzasadnienia.

Jak wskazuje Dilley, w pierwszych trzech wydaniach nie pojawia się nic takiego jak naturalizm metodologiczny. To nie dlatego, że Darwin nie przyjmował naturalizmu metodologicznego (Neal Gillespie ${ }^{21}$ zauważył, że Darwin przyjmował to stanowisko już od początku swojej kariery), lecz z tego względu, że Dar-

\footnotetext{
${ }^{18}$ Por. Francis OAKLey, „Christian Theology and the Newtonian Science: The Rise of the Concept of Laws of Nature”, Church History 1961, vol. 30, no.4, s. 433-457; John HenrY, „Voluntarist Theology at the Origins of Modern Science: A Response to Peter Harrison", History of Science 2009, vol. 47, no. 1, s. 79-113.

${ }^{19}$ Por. Peter Harrison, „Voluntarism and Early Modern Science”, History of Science 2002, vol. 40 , no. 1 , s. 63-89.

${ }^{20}$ Por. Stephen Dilley, „The Evolution of Methodological Naturalism in the Origin of Species", HOPOS: The Journal of the International Society for the History of Philosophy of Science 2013, vol. 3, no. 1, s. 20-58, http://www.jstor.org/stable/10.1086/667897 (22.11.2017).

${ }^{21}$ Por. Neal Gillespie, Charles Darwin and the Problem of Creation, University of Chicago Press, Chicago 1979.
} 
win nie czuł, iż musi posłużyć się nim jako uzasadnieniem. Dilley sugeruje, że według Darwina klimat intelektualny tamtych czasów nie pozwoliłby na akceptację takiego uzasadnienia.

W szóstym wydaniu Darwin milcząco odwołał się do doktryny niepojmowalności Boga jako do uzasadnienia wykluczenia wyjaśnień nadnaturalistycznych z biologii. Do tego wydania został dodany poniższy fragment:

Kto wierzy, że jakakolwiek dawna forma przekształciła się nagle przez działanie wewnętrznej siły lub skłonności na przykład w formę opatrzoną w skrzydła, będzie zawsze wbrew wszelkiej analogii zmuszony do przypuszczenia, że wiele osobników zmienia się równocześnie. Trudno zaprzeczyć, że takie gwałtowne i poważne zmiany budowy znacznie się różnią od tych, którym widocznie uległa większość gatunków. Będzie on dalej zmuszony do wiary w to, że wiele narządów znakomicie przystosowanych do wszystkich innych części tejże istoty i do otaczających warunków również nagle powstało, a dla tych skomplikowanych i zadziwiających przystosowań nie będzie on w stanie przytoczyć nawet cienia wyjaśnienia. Będzie też zmuszony przyznać, że te wielkie i nagłe przekształcenia nie pozostawiły w zarodku żadnego śladu swej działalności. Przypuścić to wszystko, zdaje mi się, byłoby to samo, co porzucić dziedzinę wiedzy $i$ wejść w krainę cudów. ${ }^{22}$

Innymi słowy, jeśli ktoś stwierdzi, że nastąpił cud, to już w zasadzie nie będzie mógł przytoczyć nawet cienia wyjaśnienia. Niewypowiedzianą racją dla takiego wniosku jest teza, że drogi Boga są dla nas niepojmowalne.

Ponadto, wziąwszy pod uwagę szerszy pogląd na niepojmowalność Boga, nie jest to tylko argument dotyczący Boga, ale i każdego nienaturalistycznego wyjaśnienia. Darwin zastosował tę doktrynę nie tylko do cudów, ale też do wewnętrznych niemechanicznych sił organizmów. Zaklasyfikował on tego rodzaju siły do tej samej kategorii, co cudy. Jedynym jego uzasadnieniem jest sugestia, że w takiej sytuacji nie można przytoczyć „nawet cienia wyjaśnienia”.

Ten sposób uzasadniania przetrwał do czasów współczesnych, co można dostrzec $\mathrm{w}$ różnych publikacjach na temat naturalizmu metodologicznego. Idea niepojmowalności Boga zwykle jest jednak przyjmowana milcząco, a nie jawnie. Wyraźnie sformułowane są zazwyczaj argumenty dotyczące wszechmocy Boga, nie zaś jego niepojmowalności. We współczesnej odmianie tego argumen-

\footnotetext{
${ }^{22}$ Karol DARwIN, $\mathbf{O}$ powstawaniu gatunków drogą doboru naturalnego, czyli o utrzymaniu się doskonalszych ras w walce o byt, przeł. Szymon Dickstein i Józef Nusbaum, Ediciones Altaya Polska \& DeAgostini Polska, Warszawa 2001, s. 270-271 [wyróżnienia dodane].
} 
tu mówi się, że skoro Bóg może zrobić wszystko, to jest logicznie możliwe, że wszystko, co się wydarza, stanowi skutek kaprysu Boga. Dla przykładu Barbara Forrest twierdzi, że:

Wprowadzenie wyjaśnień nadnaturalistycznych do nauki wpłynęłoby destrukcyjnie na jej siłę eksplanacyjną, ponieważ wymagałoby to wcielenia, jako zasady operacyjnej, przesłanki, zgodnie z którą dosłownie wszystko, co jest logicznie możliwe, może się urzeczywistnić, i to bez względu na jakiekolwiek i wszystkie prawa przyrody. W ten sposób unicestwiona zostałaby również stabilność nauki. ${ }^{23}$

Marteen Boudry, Stefaan Blancke i Johan Braeckman ${ }^{24}$ wskazują, że to oraz podobne twierdzenia nie są $\mathrm{w}$ istocie problematyczne, ponieważ są jedynie przeformułowaniem definicji możliwości logicznej. Jeśli jednak dołączymy doktrynę niepojmowalności Boga jako niewypowiedzianą podstawę, wówczas twierdzenie to staje się znacznie bardziej przekonujące. Gdyby działania Boga były pojmowalne, to Boska wszechmoc nie stanowiłaby takiego problemu jak opisany powyżej - odkrycie pojmowalności Boga miałoby taki sam charakter jak odkrycie pojmowalności czegokolwiek innego. Tylko przy założeniu, że Bóg jest niepojmowalny, stanowiłoby to realny problem dla nauki.

Ponadto twierdzenie Forrest nie dotyczy tylko Boga, lecz wszystkich wyjaśnień nadnaturalistycznych. Tylko przy przyjęciu szerszego poglądu na niepojmowalność Boga niewysłowiony charakter Boga rozciąga się na każdy aspekt sfery nadnaturalnej. W przeciwnym razie odkrycie pojmowalności tego, co nadnaturalne, nie różniłoby się skrajnie od odkrycia pojmowalności czegokolwiek innego. Należy jedynie ustanowić metodologię sprowadzania tego, co logicznie możliwe, do tego, co realnie możliwe.

Jak wskazują Boudry, Blancke i Braeckman, problem ten nie dotyczy wyłącznie Forrest, ale również większości współczesnych prób obrony naturalizmu metodologicznego w nauce.

\footnotetext{
${ }^{23}$ Barbara ForRest, „Methodological Naturalism and Philosophical Naturalism: Clarifying the Connection", Philo 2000, vol. 3, no. 2, s. 7-29, https://infidels.org/library/modern/barbara_for rest/naturalism.html (24.11.2017).

${ }^{24}$ Por. Marteen Boudry, Stefaan Blancke, and Johan Braeckman, „How Not to Attack Intelligent Design Creationism: Philosophical Misconceptions About Methodological Naturalism", Foundations of Science 2010, vol. 15, no. 3, s. 227-244.
} 
Podsumowując, siedemnastowieczny empiryzm był możliwy dzięki teologicznemu woluntaryzmowi, który zanegował jedynie naszą zdolność apriorycznego poznania myśli Boga. W dziewiętnastym wieku stanowisko to przekształciło się jednak w totalny sceptycyzm co do naszej zdolności do pojmowania lub zdobywania jakiejkolwiek wiedzy o Bogu, bądź nawet o czymkolwiek, co nadnaturalne albo nienaturalne. Takie właśnie jest milczace uzasadnienie, które nadaje sens współczesnym twierdzeniom na temat wiedzy teologicznej głoszonym w obronie naturalizmu metodologicznego.

To interesujące, że podstawą uzasadnienia naturalizmu metodologicznego nie są fakty empiryczne, lecz teologiczne pytania o to, co można, a czego nie można ustalić drogą empiryczną. Jeżeli celem jest wykluczenie myśli teologicznej z rozważań naukowych, to na ironię zakrawa fakt, że naturalizm metodologiczny jej nie wyklucza, lecz staje po stronie pytań teologicznych.

Ponadto odrzucenie przez Darwina przyczyn celowych doprowadziło do niepojmowalności wiedzy biologicznej. Jeśli podąży się za Darwinem, to wszystkie rozważania o przyczynach celowych w biologii należy uznać za nienaukowe. Tak pojawiły się pokolenia biologów, którzy unikali każdego rodzaju języka teleologicznego w biologii. Na początku dwudziestego wieku biologowie unikali wypowiedzi typu ,zwierzę zbudowało gniazdo $w$ celu złożenia w nim jaj”, ponieważ miało to zbyt duży posmak teleologiczny. Często natomiast stosowali wypowiedzi w rodzaju ,zwierzę zbudowało gniazdo $i$ następnie złożyło w nim jaja", redukując czynności do nieteleologicznych, mechanistycznych opisów.

Colin Pittendrigh ${ }^{25}$ i Ernst Mayr ${ }^{26}$ przywrócili język teleologiczny w biologii dzięki zastosowaniu pojęcia „teleonomia”. Interesujące jest jednak, że pomimo faktu, iż zachowania teleologiczne to podstawowe sposoby funkcjonowania organizmów, potrzeba było kilkudziesięciu lat na znalezienie luki w naturalizmie metodologicznym, która umożliwiła mówienie o teleologii w sposób zgodny z właśnie tą odmianą naturalizmu. Tak więc zamiast stanowić pomoc $\mathrm{w}$ do-

\footnotetext{
${ }^{25}$ Por. Colin Pittendrigh, „Adaptation, Natural Selection, and Behavior”, w: Anne Roe and George Gaylord Simpson (eds.), Behavior and Evolution, Yale University Press, New Haven 1958 , s. 390-416.

${ }^{26}$ Por. Ernst MAYr, „Cause and Effect in Biology”, Science 1961, vol. 134, no. 3489, s. 15011506.
} 
ciekaniach nad przedmiotem badań, takie ograniczenia komplikowały rozważania biologiczne. Można też argumentować, że Pittendrighowi i Mayrowi nie udało się skutecznie znaturalizować teleologii w biologii i że $\mathrm{w}$ istocie biologia na ogół funkcjonuje w ramach założeń teleologicznych sformułowanych w naturalistycznym języku i terminologii. ${ }^{27} \mathrm{~W}$ każdym razie jest oczywiste, że naturalizm nie powstał jako rezultat rozważań nad przedmiotem badań, lecz jako skutek zastosowania swego rodzaju rozumowania teologicznego.

W rzeczy samej, rozumowanie teologiczne stanowiło fundament dla wielu aspektów nauki. Biologię eksperymentalną zapoczątkował Francesco Redi, aby udowodnić, że organizmy zostały stworzone przez Boga według ich rodzajów i nie powstały spontanicznie. ${ }^{28}$ Gregor Mendel ${ }^{29}$ stworzył genetykę, aby pokazać, że zmienność ma ustalone granice (to jest $\mathrm{w}$ ramach stworzonych rodzajów). ${ }^{30}$ Pewien katolicki ksiądz sformułował Teorię Wielkiego Wybuchu, która

${ }^{27}$ Por. Mark Bedau, „Can Biological Teleology Be Naturalized?”, The Journal of Philosophy 1991, vol. 88, no. 11, s. 647-655; Jerry Fodor and Massimo Piattelli-Palmarin, What Darwin Got Wrong, Farrar, Straus and Giroux, New York 2010.

Kolejnym tego przykładem jest biologia systemowa, która dowodzi produktywności biologii utrzymującej, że zrozumienie celu układu jest metodologicznie równie ważne lub nawet ważniej sze niż zrozumienie jego składników (por. Arthur D. LANDER, „A Calculus of Purpose”, PLoS ONE 2004, vol. 2, no. 6, s. 0712-0714; Denis Noble, The Music of Life: Biology Beyond the Genes, Oxford University Press, Oxford 2006; David SNoKe, „Biologia systemowa jako paradygmat badawczy teorii inteligentnego projektu”, przeł. Dariusz Sagan, Filozoficzne Aspekty Genezy 2015 , t. 12, s. 255-285, http://www.nauka-a-religia.uz.zgora.pl/images/FAG/2015.t.12/art.03.pdf [24.11.2017]). Chociaż wielu biologów systemowych uznałoby swoje podejście za naturalistyczne, to metodologia stawiająca na pierwszym miejscu cel jest $\mathrm{w}$ istocie niezgodna $\mathrm{z}$ tym ujęciem.

${ }^{28}$ Redi (por. Francesco REDI, Experiments on the Generation of Insects, trans. Mab Bigelow, The Open Court Publishing Company, Chicago 1909 (1688), https://archive.org/download/ experimentsongen00redi/ [25.11.2017]) stwierdził: „Powinienem wyrazić swoje przekonanie, że Ziemia, po pojawieniu się na początku pierwszych roślin i zwierząt zgodnie z porządkiem ustanowionym przez Najwyższego i Wszechmocnego Stwórcę, od tej pory nigdy nie zrodziła żadnych roślin lub zwierząt, czy to doskonałych, czy niedoskonałych. Wszystko zaś, co zgodnie z naszą wiedzą zrodziła $\mathrm{w}$ przeszłości lub obecnie, pochodzi wyłącznie $\mathrm{z}$ prawdziwego nasienia roślin i zwierząt, które zatem, własnymi środkami, zachowują swój gatunek”. Redi rozpoczął więc swoje eksperymenty, aby dowieść prawdziwości Księgi Rodzaju, i w ten sposób dał początek dziedzinie biologii eksperymentalnej.

${ }^{29}$ Por. Gregor Mendel, „Experiments in Plant Hybridization (1865)”, http://mendelweb.org/ Mendel.plain.html (25.11.2017).

${ }^{30}$ Wskazują na to dwa ostatnie akapity artykułu Mendla. Pisze on: „Wyniki tych eksperymentów transformacyjnych doprowadziły Gärtnera do sprzeciwu wobec opinii tych przyrodników, którzy kwestionują stałość gatunków roślin i wierzą w ciągłą ewolucję roślinności. W całko- 
godziła teologię tomistyczną i Księgę Rodzaju z kosmologią. ${ }^{31}$

Zważywszy na to, że niektóre z najważniejszych teorii we współczesnej nauce powstały w kontekście teologicznym, trudno utrzymywać, że teologia już z samej zasady nie może wnosić wiedzy do badań. Wygląda raczej na to, że $\mathrm{w}$ istocie teologia odniosła spore sukcesy jako układ odniesienia różnych badań.

\section{Przywrócenie wiedzy nienaturalistycznej}

Podsumowując, wykazałem, że niemal każdy fragment oświadczenia NSTA na temat naturalizmu metodologicznego opiera się na błędnej filozofii lub teologii. Chociaż naturalizm metodologiczny może mieć sens w pewnych kontekstach, narzucenie go jako totalnego ograniczenia na wszystkie typy badań naukowych, zwłaszcza na badania totalizujące, nie ma filozoficznego uzasadnienia.

Nie należy jednak pomijać korzyści, jakie naturalizm metodologiczny przyniósł nauce. Można je wykorzystać w próbie włączenia do nauki wiedzy nienaturalistycznej. Przede wszystkim metodologiczne granice ułatwiają badania dzięki zawężeniu ich zakresu. Każdy, kto napisał dysertację, wie, jak ważne jest

witym przekształceniu jednego gatunku w drugi dostrzega on dowód na to, że gatunki są niezmienne, a zmiany zachodzą u nich tylko w pewnych granicach, których nie mogą przekroczyć. Chociaż opinii tej nie można zaakceptować bezwarunkowo, to w eksperymentach Gärtnera znajdujemy godne uwagi potwierdzenie wysuniętego już przypuszczenia w odniesieniu do zmienności roślin uprawnych”. Carl Friedrich von Gärtner (1772-1850) był wiodącym kreacjonistą tamtych czasów, a Mendel opisuje tu, dlaczego jego system genetyki zgodny jest $\mathrm{z}$ wynikami badań Gärtnera.

${ }^{31}$ Wielu ludzi sądzi, że Georges Lemaître całkowicie oddzielał swoją naukę od teologii. Świadectwa przemawiają jednak za tym, że prywatnie Lemaître zamierzał stworzyć kosmologię, która połączyłaby jego tomistyczną teologię z nauką. Publicznie Lemaître wypowiadał takie twierdzenia: „Z tego, co widzę, taka teoria jest zupełnie niezależna od jakiegokolwiek metafizycznego lub religijnego zagadnienia” (Rodney D. HoLDER, „Georges Lemaitre and Fred Hoyle: Contrasting Characters in Science and Religion”, w: Rodney D. Holder and Simon Mitton (eds.), Georges Lemaître: Life, Science, and Legacy, Springer, Heidelberg 2012, s. 50 [39-55]). Jego nieopublikowane prace pokazują jednak, że według niego Teoria Wielkiego Wybuchu potwierdza Księgę Rodzaju (por. Holder, „Georges Lemaître and Fred Hoyle...”, s. 49). Istnieją ponadto doniesienia, że w prywatnych rozmowach odbywanych w czasie, gdy zaczął pracować nad swoją teorią, wskazywał, że Teoria Wielkiego Wybuchu godzi tomizm z nauka (por. Anthony L. PeratT, „Dean of the Plasma Dissidents”, The World and I May 1988, s. 196 [190-197], http://plasmauni verse.info/downloads/DeanOfPlasma.pdf [25.11.2017]). 
zawężenie zakresu badań, aby dało się formułować autorytatywne stwierdzenia. Takie granice wymagane są w przypadku skutecznej ekstrapolacji danych empirycznych. Po drugie, naturalizm metodologiczny zawiera w sobie (za sprawą pozytywizmu) system ograniczania i uzasadniania.

Naturalizm metodologiczny ograniczył zakres badań na tyle, aby różne badania były wykonalne, i zapewnił system uzasadniania, którym można się posłużyć do zewnętrznego uprawomocniania twierdzeń. System ten nie funkcjonuje bezbłędnie i nie zawsze jest stosowany. Jednak dysponowanie gotowym układem odniesienia daje wszystkim uprawiającym naukę wspólny punkt odniesienia dla rozważania i analizowania twierdzeń. Zdefiniuję metodologiczny układ odniesienia jako połączenie ograniczenia badań i systemu uzasadniania. Jako metodologiczny układ odniesienia naturalizm metodologiczny ogranicza się do obiektów wykazujących zachowanie mechaniczne, a jako system uzasadniania obiera pozytywizm.

Aby dało się skutecznie uprawiać naukę poza ramami naturalizmu metodologicznego, potrzebne są dwie rzeczy. Po pierwsze, wymagane są nowe metodologiczne układy odniesienia dla różnych przedmiotów i typów badań. Po drugie, niezbędna jest metoda integracji metodologicznych układów odniesienia, która umożliwiałaby łączenie wiedzy z różnych dyscyplin i działów badań. Dla przykładu Sam Rakover ${ }^{32}$ podejmuje próbę wprowadzenia pewnego metodologicznego układu odniesienia do psychologii. To dopiero pierwszy krok, ale zaproponowany przez niego układ odniesienia obejmuje narzucenie ograniczeń na przedmiot badań, system uzasadniania i pewne zalążki metody integrowania go $\mathrm{z}$ innymi typami badań.

Sama nauka, podobnie jak współczesna koncepcja naturalizmu metodologicznego, powstała jako skutek rozważań o charakterze filozoficznym i teologicznym. Alexander Sich ${ }^{33}$ wskazuje, że nauka nie może ani uzasadnić swych własnych zasad, ani uprawomocnić swej zdolności prowadzenia uczonych do prawdy. Do tego niezbędne są filozofia i teologia. W związku z tym powinniśmy zwrócić się w stronę filozofii i teologii, by móc ustanowić nowe metodologiczne

\footnotetext{
${ }^{32}$ Por. Sam S. Rakover, „Psychology: Methodological Dualism and a Multi-Explanation Framework - An Approach Needed for Understanding Behavior", w: BartletT and HollowaY (eds.), Naturalism and Its Alternatives in Scientific Methodologies..., s. 211-228.

${ }^{33}$ Por. SicH, „The Independence and Proper Roles of Metaphysics...”.
} 
układy odniesienia dla badań, zasady ich funkcjonowania oraz uprawomocnić ich zdolność prowadzenia uczonych do prawdy.

Jonathan Bartlett

\section{Bibliografia}

Barrett Justin L., Cognitive Science, Religion, and Theology: From Human Minds to Divine Minds, Templeton Press, West Conshohocken 2011.

BartLEtt Jonathan, „Describable But Not Predictable: Mathematical Modeling and NonNaturalistic Causation", w: Bartlett and Holloway (eds.), Naturalism and Its Alternatives in Scientific Methodologies..., s. 113-127.

Bartlett Jonathan, „Introduction”, w: Bartlett, Halsmer, and Hall (eds.), Engineering and the Ultimate..., s. 1-8.

Bartlett Jonathan, „Using Turing Oracles in Cognitive Models of Problem-Solving”, w: Bartlett, Halsmer, and Hall (eds.), Engineering and the Ultimate..., s. 99-122.

Bartlett Jonathan, Halsmer Dominic, and Hall Mark (eds.), Engineering and the Ultimate: An Interdisciplinary Investigation of Order and Design in Nature and Craft, Blyth Institute Press, Broken Arrow, Oklahoma 2014.

Bartlett Jonathan and Holloway Eric (eds.), Naturalism and Its Alternatives in Scientific Methodologies: Proceedings of the $\mathbf{2 0 1 6}$ Conference on Alternatives to Methodological Naturalism, Blyth Institute Press, Broken Arrow, Oklahoma 2017.

Bedau Mark, „Can Biological Teleology Be Naturalized?”, The Journal of Philosophy 1991, vol. 88, no. 11, s. 647-655.

Boudry Marteen, Blancke Stefaan, and Braeckman Johan, „How Not to Attack Intelligent Design Creationism: Philosophical Misconceptions About Methodological Naturalism", Foundations of Science 2010, vol. 15, no. 3, s. 227-244.

Boyer Pascal, „Religion: Bound to Believe?”, Nature 2008, vol. 455, s. 1038-1039.

DARwIN Karol, O powstawaniu gatunków drogą doboru naturalnego, czyli o utrzymaniu się doskonalszych ras w walce o byt, przeł. Szymon Dickstein i Józef Nusbaum, Ediciones Altaya Polska \& DeAgostini Polska, Warszawa 2001.

de LaPlace Pierre Simon, A Philosophical Essay on Probabilities, trans. Frederick Wilson Truscott and Frederick Lincoln Emory, John Wiley \& Sons, London 1902 (1814), http://ba yes.wustl.edu/Manual/laplace_A_philosophical_essay_on_probabilities.pdf (15.11.2017). 
Dilley Stephen, „The Evolution of Methodological Naturalism in the Origin of Species”, HOPOS: The Journal of the International Society for the History of Philosophy of Science 2013, vol. 3, no. 1, s. 20-58, http://www.jstor.org/stable/10.1086/667897 (22.11.2017).

Feyerabend Paul K., Przeciw metodzie, przeł. Stefan Wiertlewski, Siedmioróg, Wrocław 2001.

Fodor Jerry and Piattelli-Palmarin Massimo, What Darwin Got Wrong, Farrar, Straus and Giroux, New York 2010.

FoRREST Barbara, „Methodological Naturalism and Philosophical Naturalism: Clarifying the Connection", Philo 2000, vol. 3, no. 2, s. 7-29, https://infidels.org/library/modern/barbara forrest/naturalism.html (24.11.2017).

Gillespie Neal, Charles Darwin and the Problem of Creation, University of Chicago Press, Chicago 1979.

Hаскетт Conrad and Grim Brian J., „The Global Religious Landscape”, The Pew Forum on Religion and Public Life 18 December 2012, http://www.pewforum.org/2012/12/18/globalreligious-landscape-exec/ (08.08.2017).

Hanson Norwood Russell, Patterns of Discovery, Cambridge University Press, Cambridge 1958.

HarRISON Peter, „Voluntarism and Early Modern Science”, History of Science 2002, vol. 40, no. 1 , s. 63-89.

HenRY John, ,Voluntarist Theology at the Origins of Modern Science: A Response to Peter Harrison", History of Science 2009, vol. 47, no. 1, s. 79-113.

HoLDER Rodney D., „Georges Lemaitre and Fred Hoyle: Contrasting Characters in Science and Religion”, w: HoLDER and MitTon (eds.), Georges Lemaître..., s. 39-55.

Holder Rodney D. and Mitton Simon (eds.), Georges Lemaître: Life, Science, and Legacy, Springer, Heidelberg 2012.

James William, Pragmatyzm. Nowe imię paru starych stylów myślenia, przeł. Michał Szczubiałka, Wydawnictwo KR, Warszawa 1998.

KatsKee Richard B., „Why It Mattered to Dover That Intelligent Design Isn’t Science”, First Amendment Law Review 2006, vol. 5, s. 112-146, http://tiny.pl/g18np (12.07.2017).

LANDER Arthur D., ,A Calculus of Purpose”, PLoS ONE 2004, vol. 2, no. 6, s. 0712-0714.

Leibniz Gottfried Wilhelm, „Polemika z Clarke'iem. Czwarte pismo Leibniza”, w: Leibniz, Wyznanie wiary filozofa..., s. 346-354.

LEIBNIz Gottfried Wilhelm, Wyznanie wiary filozofa, rozprawa metafizyczna, monadologia, zasady natury i laski oraz inne pisma filozoficzne, przeł. Stanisław Cichowicz, Juliusz Domański, Henryk Krzeczkowski i Henryk Moese, Biblioteka Klasyków Filozofii, Państwowe Wydawnictwo Naukowe, Warszawa 1969. 
Lerner Lawrence S., Good Science, Bad Science: Teaching Evolution in the States, Thomas B. Fordham Foundation 2000, https://edex.s3-us-west-2.amazonaws.com/publica tion/pdfs/lerner_7.pdf(12.07.2017).

MAYr Ernst, „Cause and Effect in Biology”, Science 1961, vol. 134, no. 3489, s. 15011506.

Mendel Gregor, „Experiments in Plant Hybridization (1865)”, http://mendelweb.org/Men del.plain.html (25.11.2017)

National Science Teachers Association, „NSTA Position Statement on the Teaching of Evolution”, 2013, http://www.nsta.org/about/positions/evolution.aspx (11.07.2017).

Next Generation Science Standards: For States, By States, National Academies Press, Washington, DC. 2013.

NGSS Lead States, „Appendix h: Understanding the Scientific Enterprise: The Nature of Science in the Next Generation Science Standards", w: Next Generation Science Standards..., s. 430-436.

NiEBuHR Reinhold, The Irony of American History, Scribner, New York 1952.

Noble Denis, The Music of Life: Biology Beyond the Genes, Oxford University Press, Oxford 2006.

OAKLEY Francis, „Christian Theology and the Newtonian Science: The Rise of the Concept of Laws of Nature", Church History 1961, vol. 30, no.4, s. 433-457.

Peratt Anthony L., „Dean of the Plasma Dissidents”, The World and I May 1988, s. 190197, http://plasmauniverse.info/downloads/DeanOfPlasma.pdf (25.11.2017).

Pittendrigh Colin, „Adaptation, Natural Selection, and Behavior”, w: RoE and Simpson (eds.), Behavior and Evolution..., s. 390-416.

Polanyi Michael, Science, Faith, and Society, Oxford University Press, Oxford 1946.

Polkinghorne John, Belief in God in an Age of Science, Yale University Press, New Haven and London 1998.

Quine Willard Van Orman, „Ontological Relativity”, The Journal of Philosophy 1968, vol. 65 , no. 7, s. 185-212.

Rakover Sam S., „Psychology: Methodological Dualism and a Multi-Explanation Framework - An Approach Needed for Understanding Behavior", w: BartLETT and HollowaY (eds.), Naturalism and Its Alternatives in Scientific Methodologies..., s. 211-228.

REDI Francesco, Experiments on the Generation of Insects, trans. Mab Bigelow, The Open Court Publishing Company, Chicago 1909 (1688), https://archive.org/download/expe rimentsongen00redi/ (25.11.2017). 
Roe Anne and Simpson George Gaylord (eds.), Behavior and Evolution, Yale University Press, New Haven 1958.

SC Education Oversight Committee, „Special Panel of the State Board of Education and EOC Regarding High School Biology Standard H.B.5. (July 29, 2014)”, http://tiny.pl/g 18 nw.

Scharmann Lawrence C., „A Proactive Strategy for Teaching Evolution”, The American Biology Teacher 2015, vol. 67, no. 1, s. 12-16.

Sich Alexander, „The Independence and Proper Roles of Metaphysics in Support of an Integrated Understanding of God's Creation”, w: Bartlett, Halsmer, and Hall (eds.), Engineering and the Ultimate..., s. 39-62.

Slowik Edward, „Descartes’ Physics”, w: ZalTa (ed.), The Stanford Encyclopedia of Philosophy..., https://plato.stanford.edu/archives/sum2014/entries/descartes-physics/ (02.08. 2017).

SNOKE David, „Biologia systemowa jako paradygmat badawczy teorii inteligentnego projektu", przeł. Dariusz Sagan, Filozoficzne Aspekty Genezy 2015, t. 12, s. 255-285, http:// www.nauka-a-religia.uz.zgora.pl/images/FAG/2015.t.12/art.03.pdf (24.11.2017).

Sproul Richard C., „Divine Incomprehensibility”, Tabletalk Magazine August 2014, https://tabletalkmagazine.com/article/2014/08/divine-incomprehensibility/ (22.11.2017).

van Rools Iris, „The Tractable Cognition Thesis”, Cognitive Science: A Multidisciplinary Journal 2008, vol. 32, no. 6, s. 939-984, http://onlinelibrary.wiley.com/doi/10.1080/036402 10801897856/pdf (16.11.2017).

Wolfram Stephen, A New Kind of Science, Wolfram Media 2002.

Working Group on Teaching Evolution, National Academy of Sciences, Teaching About Evolution and the Nature of Science, National Academy Press, Washington, DC. 1998.

Zalta Edward N. (ed.), The Stanford Encyclopedia of Philosophy, Summer 2014 Edition.

\section{Filozoficzne wady naturalizmu metodologicznego i perspektywy na przyszlość}

\section{Streszczenie}

Podstawą naturalizmu metodologicznego, służącego wzmocnieniu ekskluzjonistycznego poglądu na badania naukowe, są trzy problematyczne nurty filozofii: filozofia mechanistyczna, pozytywistyczna epistemologia i doktryna niepojmowalności Boga. Każda z tych filozofii posiada wewnętrzne wady, przez które stanowiska te nie są w stanie objąć pełnego zakresu związków przyczynowych, jakie usiłuje badać nauka. Jednak pomimo tych problemów, omawiany tu rodzaj naturalizmu wykazuje, jako metodologia, pewne pozytywne ce- 
chy, które należałoby zachować, nawet jeżeli sam naturalizm metodologiczny jest nie do utrzymania.

Slowa kluczowe: naturalizm metodologiczny, filozofia mechanistyczna, pozytywizm, pragmatyzm, niepojmowalność Boga, teleologia, metodologiczny układ odniesienia.

\section{Philosophical Shortcomings of Methodological Naturalism and the Path Forward}

\section{Summary}

Methodological naturalism, when used to enforce an exclusive view of scientific investigation, is based on three problematic streams of philosophy: mechanical philosophy, positivistic epistemology, and divine incomprehensibility. Each of these philosophies has inherent flaws that prevent them from being usable across the entirety of causal relationships that science attempts to investigate. However, even in the face of such criticisms, methodological naturalism as a methodology does have some positive features that should be retained even if methodological naturalism itself is not.

Keywords: methodological naturalism, mechanical philosophy, positivism, pragmatism, divine incomprehensibility, teleology, methodological framework. 